UDC [614.4+314.4]/316.35

DOI: 10.21668/health.risk/2019.2.10.eng

\title{
ASSESSMENT OF CORRELATION BETWEEN HETEROGENEOUS RISK FACTORS AND MORBIDITY AMONG WORKING POPULATION IN RUSSIAN REGIONS WITH DIFFERENT BACKGROUND OF HEALTH FORMATION
}

\author{
N.A. Lebedeva-Nesevrya ${ }^{1}$, A.O. Barg', M.Yu. Tsinker², V.G. Kostarev ${ }^{3}$ \\ ${ }^{1}$ Perm State University, 15 Bukireva Str., Perm, 614990, Russian Federation \\ ${ }^{2}$ Federal Scientific Center for Medical and Preventive Health Risk Management Technologies, 82 Monastyrskaya \\ Str., Perm, 614045, Russian Federation \\ ${ }^{3}$ Federal Service for Surveillance over Consumer Rights protection and Human Well-being, Perm regional office, \\ 50 Kuibyisheva Str., Perm, 614016, Russian Federation
}

The research focuses on classifying Russian regions as per their sanitary-hygienic and social-economic welfare, as well as on assessing (for certain nosologies) correlations between heterogeneous risk factors and morbidity with temporary disability among working population. The RF regions were classified (with k-average cluster analysis) as per their sanitaryhygienic and social-economic welfare in order to spot out territories with similar "background" for formation of working population health.We used data provided by the Federal Statistic Service (as per the RF regions) collected in 2016 as our empiric base. As per cluster analysis results, we assigned the RF regions into four specific categories, namely "ill-being", "moderately ill-being", "moderately well-being", and "well-being" (the obtained data are visualized on the map of the country). The performed correlation-regression analysis allowed us to obtain more than twenty authentic models that described correlations between various factors and morbidity with temporary disability among working population. We calculated determination coefficient $R^{2}$ for each model that characterized a share of explained variation in a health parameter caused by a factor that was considered in a model. We paid special attention to the 1st cluster that had the least favorable background for health formation (here we detected most apparent influence exerted by social and economic factors on analyzed health parameters of working population). The $2^{\text {nd }}$ clyster was also examined thoroughly as it was characterized with the highest morbidity among working population (we revealed that social-hygienic welfare on territories belonging to this cluster had greater influence on health parameters than social and economic one).Our data can be appliedto create federal and regional programs aimed at preserving and improving working population health.

Key words: working population, morbidity with temporary mortality, heterogeneous health risk factors.

National targets to be reached and strategic development tasks to be solved in the RF over a period of time up to 2024 are fixed in the RF President Order dated May 07, 2018. They are all aimed at streamlining and speeding up technologic development of the country, as well as at providing economic growth rates higher than average ones in the world. All that should result in Russia taking its place among the top five economies in the world ${ }^{1}$.
These plans are quite ambitious and they require high-quality labor resources that can provide relevant labor productivity. Russian workers employed at enterprises and companies are assumed to be highly-qualified professionals and to have intellectual and innovative potential as well as good health. The latter is a significant issue given decreasing number of population and a growth in average age of employable population in the country which oc-

(C) Lebedeva-Nesevrya N.A., Barg A.O., Tsinker M.Yu., Kostarev V.G., 2019

Natalya A. Lebedeva-Nesevrya - Doctor of Sociological Sciences, Associate Professor, Head of Laboratory for Social Risks Analysis Techniques, Professor at Sociology Department (e-mail: natnes@fcrisk.ru; tel.: +7 (342) 237-25-34; ORCID: https: //orcid.org/0000-0003-3036-3542).

Anastasiya O. Barg - Candidate of Sociological Sciences, Associate Professor at the Department of Sociology (e-mail: an-bg@yandex.ru; tel.: +7 (342) 239-63-29; ORCID: https: //orcid.org/0000-0003-2901-3932).

Mikhail Y. Tsinker - junior research associate of Department of Mathematical Modeling of Systems and Processes (e-mail: cinker@fcrisk.ru; tel.: +7 (342) 237-18-04; ORCID: https: //orcid.org/0000-0002-2639-5368).

Vitalii G. Kostarev - Candidate of Medical Sciences, Chief State Sanitary inspector in Perm region, Head of Rospotrebnadzor office in Perm region (e-mail: urpn@59.rospotrebnadzor.ru; tel.: +7 (342) 239-35-63).

${ }^{1}$ On national targets and strategic tasks of the Russian Federation development for the period up to 2024. - The RF President Order dated May 7, 2018 No. 204. - M., 2018. - 19 p. 
curs, among other things, due to a planned increase of the retirement age.

Preservation and improvement of workers' health in Russia is most often considered to be dependent on minimizing effects produced by occupational risk factors. Impacts exerted by occupational factors and working conditions on mortality and morbidity among employable population have been proven by research performed in the North America [1-3], Europe [4-6], and Russia [7-10]. A considerable number of studies on occupational morbidity and industrial injuries have been accomplished in Russian regions [11-15]. Their results allow concluding that all regions in Russia differ significantly as per health parameters of employable population; it is determined not only by peculiarities related to employment and working conditions, but also by anthropogenic contamination of the environment [16], and in some Russian regions also by climatic factors (low temperatures [17, 18], significant discrepancies in average temperatures in warm and cold seasons [19], a regional climate being too windy [20]). An extent to which people pursue health-preserving life style also influences their health greatly [21-23]; it is also true for social and economic context of workers' life [24, 25]. Impacts exerted by social and economic ill-being of a territory on mortality and morbidity among employable population are determined by a limited access to medical aid [26], poor living conditions [27], and prevalence of hazardous behavioral attitudes as regards health [28-30]. Besides, poor social and economic development of the country, frequent financial crises, and decreasing population incomes are able to create intensive (chronic) "social stress" [31].

Our research goal was to classify Russian regions as per sanitary-hygienic and social-economic welfare as well as to assess correlations between heterogeneous factors and parameters of morbidity with temporary disability among working population (for each specific category).

Data and methods. RF regions were classified via k-cluster analysis as per their sanitary-hygienic and social-economic welfare; it was done in order to spot out territories with similar "background" for formation of working population's health. Our empiric data were taken from the Federal State Statistics Service (as per RF regions); we used data for 2016. To determine sanitary-hygienic welfare in a region, we applied three parameters that characterized anthropogenic burden on the environment:

a) a share of ambient air samples not conforming to hygienic standards (\%);

b) a share of drinking water samples deviating from hygienic standards as per sanitarychemical parameters $(\%)$;

c) a share of soils samples not conforming to hygienic standards as per sanitary-chemical parameters $(\%)$.

We analyzed social-economic welfare in a region as per three macro-parameters that usually determined more particular socioeconomic ones:

a) adjusted gross regional product per capita (gross added value) (rubles);

b) specific weight of dilapidated housing in the overall housing stock (\%);

c) population's purchasing power which is calculated as a ratio of average population incomes per capita to a living wage fixed in a specific RF region.

To assess working population's health in regions assigned into different clusters, we applied the following parameters of morbidity with temporary disability: a) a number of temporary disability cases (as per 100 workers), b) a number of days during which a worker was temporarily disabled (as per 100 workers in general, and as per sex as well), c) average duration of 1 temporary disability case.

We applied correlation-regression analysis for regions in each cluster to determine correlations between an extended list of various risk factors and morbidity with temporary disability among working population. Parameters related to sanitary-hygienic factors included a number of examined drinking water samples with hazardous chemicals contents higher than MPC; a number of examined samples taken from centralized water supply systems that didn't conform to hygienic standards (\%); a number of examined soil samples taken in settlements that didn't conform to hygienic standards (\%); a number of examined ambient air samples taken in cities and rural settle- 
ments that contained hazardous chemicals in concentrations higher than MPC (\%); a share of examined objects that didn't conform to hygienic standards as per noise (\%); a share of examined objects that didn't conform to sanitary standards as per vibration (\%); a share of examined objects that didn't conform to hygienic standards as per electromagnetic radiation (\%). We applied the following social-economic factors in our analysis: value of the national wealth (value of fixed assets in various branches) per capita (rubles); investments into fixed capital per capita (rubles); unemployment rate (as per WLO methodology, \%); expenses on education (rubles/person); expenses on public healthcare (rubles/person); number of physicians (all specialties; per 1 thousand people); number of nurses (per 1 thousand people); a living wage fixed in a region (rubles): average population incomes per capita (rubles); a ratio of average incomes per capita to a living wage (\%); average monthly wage paid to an employed (rubles); a share of people with incomes lower than a living wage (\%); a number of families who were provided with housing or improved their housing conditions on their own, a ratio to overall population; a share of housing without centralized water supply (\%); a share of housing without sewerage (\%); specific weight of housing equipped with centralized heating.

Results and discussion. Cluster analysis results allowed assigning RF regions into four different clusters. The first cluster included regions where the situation was the worst in terms of both sanitary-hygienic and socialeconomic situation there; there were 19 RF regions assigned into it. They were predominantly located in the Far East Federal District (Jewish Autonomous Area, Primorye region, Yakutia, and Khabarovsk region) and Siberia Federal District (Transbaikal region, Irkutsk region, Kemerovo region, Krasnoyarsk region, Novosibirsk region, Buryatia Republic, Tyva Republic) (Figure). Kurgan region and Chelyabinsk region from the Urals Federal District were also included into this cluster as well as Kirov region and Saratov region from the Privolzhskiy Federal District. This cluster also included Kursk region, Murmansk region, Ingushetia Republic, and Crimea Republic. The cluster had the highest share of ambient air samples that didn't conform to hygienic standards (average cluster value was $1.89 \%$ ); soils samples not conforming to hygienic standards $(10.38 \%)$; and the highest specific weight of dilapidated housing in the overall housing stock; purchasing power was the lowest in this cluster (2.36). Morbidity with temporary disability was not critical in this cluster as most examined parameters were close to average country values excluding "average duration of 1 temporary disability case" that amounted to 14.4 days in 2016.

The second cluster that included regions where a situation was "moderately adverse" had the highest share of drinking water samples that didn't conform to hygienic standards (39\%). A share of dilapidated housing in the overall housing stock was also high in this cluster (4.4\%). Other sanitary-hygienic and socialeconomic parameters were close to average country values but morbidity with temporary disability could be considered too high as actually four out of five parameters related to it were the highest in RF regions included into this cluster. A number of temporary disability cases amounted to 47.17 per 100 employed, and a number of days during which a person was off sick amounted to 643 (overall) per 100 employed, 737.9 (women), 598.2 (men).

Almost half of the regions located in the Central Federal District were assigned into this cluster (Vladimir region, Ivanovo region, Kostroma region, Smolensk region, Tver' region, Tula region, and Yaroslavl region), together with neighboring Novgorod region. Besides, the cluster included three more regions from the North-West Federal District (Arkhangelsk region, Leningrad region, and Karelia). Also some southern regions were ranked as being "moderately adverse": they were Rostov region, Dagestan, and Kalmykia; it included several "Siberian" regions, such as Komi Republic, Tomsk region, and Khanty-Mansi Autonomous Area and two regions from the Privolzhskiy Federal District, namely Perm region and Mordovia, and two regions from the Far East Federal District (Amur region and Magadan region). Overall, there were 21 RF regions in the second cluster. 


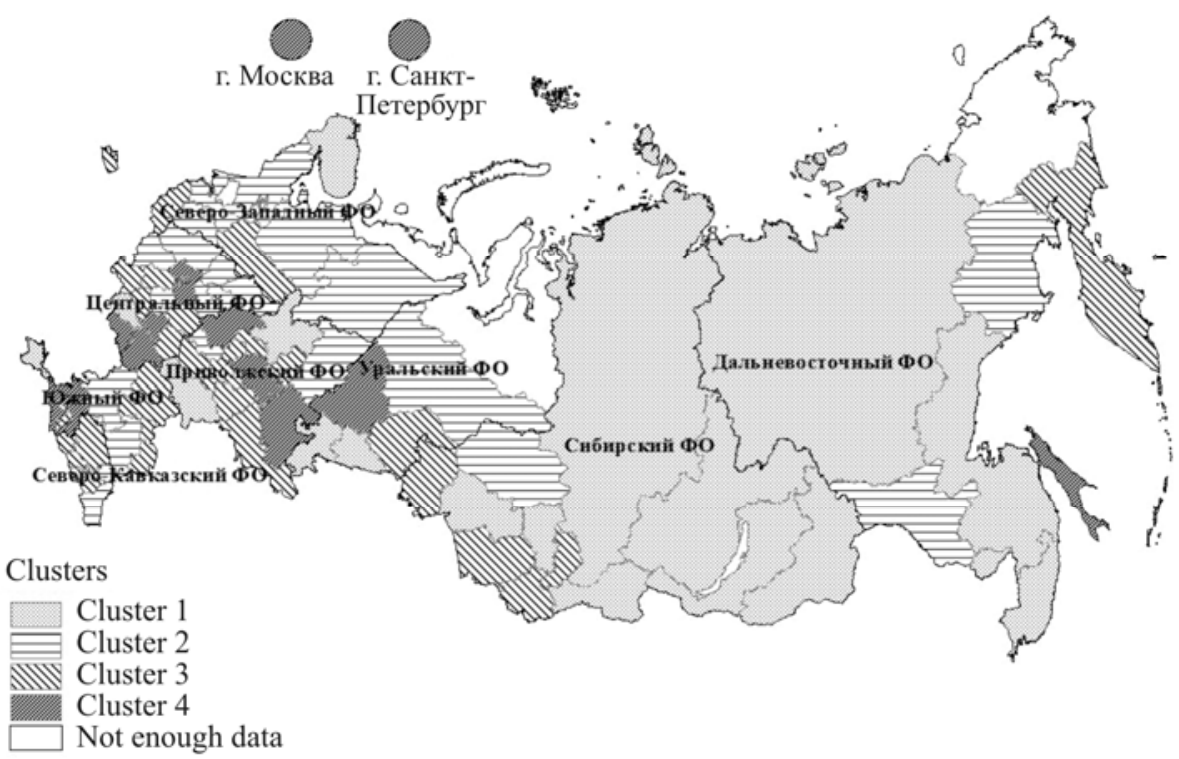

Figure. RF regions assigned into different clusters as per sanitary-hygienic and social-economic welfare

Table

Average values of social-economic and sanitary-hygienic parameters and temporary morbidity among employed population in clusters and in the country as a whole

\begin{tabular}{|c|c|c|c|c|c|}
\hline \multirow{2}{*}{ Parameters } & \multicolumn{4}{|c|}{ Average value in a cluster } & \multirow{2}{*}{$\begin{array}{l}\text { Average } \\
\text { in RF }\end{array}$} \\
\hline & 1 & 2 & 3 & 4 & \\
\hline $\begin{array}{l}\text { Examined ambient air samples with chemicals in } \\
\text { concentrations higher than MPC, } \%\end{array}$ & 1.89 & 0.17 & 0.34 & 0.43 & 0.67 \\
\hline $\begin{array}{l}\text { Examined samples of water taken from centralized } \\
\text { water supply systems not conforming to hygienic } \\
\text { standards as per sanitary-chemical parameters, \% }\end{array}$ & 15.64 & 39.01 & 8.59 & 14.32 & 18.93 \\
\hline $\begin{array}{l}\text { Examined soils samples taken in settlements not } \\
\text { conforming to hygienic standards as per sanitary- } \\
\text { chemical parameters, \% }\end{array}$ & 10.38 & 3.05 & 2.44 & 6.23 & 5.04 \\
\hline Purchasing power & 2.36 & 2.65 & 2.55 & 3.69 & 2.71 \\
\hline Share of dilapidated housing, \% & 5.14 & 4.40 & 2.32 & 2.46 & 3.53 \\
\hline Gross regional product per capita (billion rubles) & 768.81 & 772.28 & 517.49 & 3522.84 & 1117.43 \\
\hline $\begin{array}{l}\text { A number of days during which a person is off sick } \\
\text { per } 100 \text { employed }\end{array}$ & 606.97 & 643.09 & 614.83 & 566.54 & 612.59 \\
\hline $\begin{array}{l}\text { A number of temporary disability cases per } 100 \text { em- } \\
\text { ployed }\end{array}$ & 42.23 & 47.17 & 45.23 & 42.07 & 44.53 \\
\hline Average duration of 1 temporary disability case & 14.44 & 13.67 & 13.61 & 13.44 & 13.79 \\
\hline $\begin{array}{l}\text { A number of days during which a person is off sick } \\
\text { per } 100 \text { employed (men) }\end{array}$ & 555.48 & 598.25 & 567.26 & 567.54 & 572.51 \\
\hline $\begin{array}{l}\text { A number of days during which a person is off sick } \\
\text { per } 100 \text { employed (women) }\end{array}$ & 675.19 & 737.94 & 674.61 & 655.22 & 687.89 \\
\hline
\end{tabular}

The third cluster was made up of "conditionally well" regions; only one parameter here ("adjusted gross regional product") was the lowest among all the clusters (517.4 billion rubles). All other parameters were close to av- erage values, and "share of dilapidated housing in the overall housing stock" and "share of soils samples not conforming to hygienic standards" were the lowest in this cluster, $2.32 \%$ and $2.44 \%$ respectively (Table). 
The third cluster included $29 \mathrm{RF}$ regions, among them 10 Republics (Kabardino-Balkaria, Karachai-Cherkess, North Ossetia, Chechnya, and Chuvashia from the North-Caucasian Federal District, as well as Adygei, Altai Republic, Mari El, Khalassia, and Udmurtia. There were also five regions from the Central Federal District (Bryansk region, Kaluga region, Orel region, Ryazan region, and Tanbov region); four regions form the Privolzhskiy Federal District (Orenburg region, Penza region, Samara region, and Ulyanovsk region); three regions from the North-West Federal District (Vologda region, Kaliningrad region, and Pskov region); two regions from the Southern Federal District (Astrakhan region and Volgograd region) and the Siberian Federal District (Altai region and Omsk region) in this cluster; it also included Stavropol region, Kamchatka, and Tyumen region.

The fourth cluster where the situation was the safest and most favorable was the smallest one and included only $13 \mathrm{RF}$ regions. First of all, they were Moscow city and SaintPetersburg (federal cities); secondly, there were so called "federal regions" such as Krasnodar region, Moscow region, Bashkortostan, Tatarstan, and Sverdlovsk region; thirdly, the cluster included regions that were rich with mineral resources, namely Sakhalin and Yamal-Nenets Autonomous Area. This cluster also included Belgorod region, Voronezh region, Lipetsk region, and Nizhniy Novgorod region.

Regions in the fourth cluster had the highest gross regional product (average cluster value was 3,522 billion rubles) and purchasing power (average cluster value was 3.69); share of dilapidated housing in the overall housing stock was relatively low and amounted to $2.46 \%$. Sanitary-hygienic well-being was a bit lower than social-economic one as regions from the cluster held the second rank place as per air and soils samples not conforming to hygienic standards just after the most unfavorable first cluster. Morbidity parameters were among the lowest; it was true for a number of temporary disability cases (42.07 per 100 employed), average duration of one temporary disability case (13.44 days), and a number of days during which a worker was off sick (566.5 per 100 employed overall; 655.22 per 100 employed women).
Our next step was to assess correlations between specific social-economic and sanitary-hygienic factors and morbidity with temporary disability among employed population; to do that, we took the above-mentioned cluster analysis results into account. Correlationregression analysis allowed us to obtain several dozens of authentic pair models that described those correlations. We also calculated determination coefficient $\mathrm{R}^{2}$ for each model; it described a share of explained variations in a health parameter caused by a factor considered in a model. We paid special attention to the first cluster as a background situation for health formation was the least favorable there, and to the second one as morbidity among employed population was the highest there.

We detected "factor - effect" relationships between certain social and economic factors and morbidity with temporary disability among employed people in the first cluster:

between investments into fixed capital per capita and a number of days during which a worker was off sick per 100 employed men (correlation coefficient was equal to $(-0.37)$, at $\mathrm{p}=0.003$, a moderate correlation, $\left.\mathrm{R}^{2}=0.14\right)$; number of days during which a worker was off sick per 100 employed (overall) (correlation coefficient was equal to $(-0.38)$, at $p=0.003$, a moderate correlation, $\left.\mathrm{R}^{2}=0.14\right)$; a number of temporary disability cases per 100 employed (correlation coefficient was equal to (-0.29), at $\mathrm{p}=0.025$, a weak correlation, $\left.\mathrm{R}^{2}=0.08\right)$;

between living wage and number of days during which a worker was off sick per 100 employed men (correlation coefficient was equal to $(-0.25)$, at $p=0.047$, a weak correlation, $\mathrm{R}^{2}=0.06$ ); number of days during which a worker was off sick per 100 employed (overall) (correlation coefficient was equal to $(-0.25)$, at $\mathrm{p}=0.049$, a weak correlation, $\left.\mathrm{R}^{2}=0.06\right)$; a number of temporary disability cases per 100 employed (correlation coefficient was equal to $(-0.36)$, at $p=0.004$, a moderate correlation, $\left.\mathrm{R}^{2}=0.13\right)$;

between average income per capita and a number of days during which a worker was off sick per 100 employed men (correlation coefficient was equal to $(-0.27)$, at $p=0.035$, a weak correlation, $\mathrm{R}^{2}=0.07$ ), and a similar negative correlation was also detected in the fourth 
("the most favorable") cluster (the correlation coefficient was equal to $(-0.49)$, at $\mathrm{p}=0.002$, a moderate correlation, $\left.\mathrm{R}^{2}=0.24\right)$; a number of days during which a worker was off sick per 100 employed (overall) (correlation coefficient was equal to $(-0.34)$, at $\mathrm{p}=0.006$, a moderate correlation, $\left.\mathrm{R}^{2}=0.12\right)$; a number of temporary disability cases per 100 employed (correlation coefficient was equal to $(-0.31)$, at $p=0.015$, a moderate correlation, $\mathrm{R}^{2}=0.10$ );

There was a correlation between average wages paid to employed people and a number of days during which a worker was off sick per 100 employed men (correlation coefficient was equal to $(-0.29)$, at $\mathrm{p}=0.021$, a weak correlation, $\mathrm{R}^{2}=0.08$ ), and a similar negative correlation was also detected in the fourth ("the most favorable") cluster (correlation coefficient was equal to $(-0.48)$, at $\mathrm{p}=0.002$, a moderate correlation, $\mathrm{R}^{2}=0.23$ ); a number of days during which a worker was off sick per 100 employed (overall) (correlation coefficient was equal to $(-0.34)$, at $\mathrm{p}=0.007$, a moderate correlation, $\left.\mathrm{R}^{2}=0.11\right)$; a number of temporary disability cases per 100 employed (correlation coefficient was equal to $(-0.29)$, at $\mathrm{p}=0.024$, a weak correlation, $\left.\mathrm{R}^{2}=0.08\right)$;

There was a correlation between unemployment (calculated as per WLO methodology) and a number of days during which a worker was off sick per 100 employed men (correlation coefficient was equal to $(-0.37)$, at $\mathrm{p}=0.003$, a moderate correlation, $\left.\mathrm{R}^{2}=0.14\right)$; $\mathrm{a}$ number of days during which a worker was off sick per 100 employed (overall) (correlation coefficient was equal to $(-0.28)$, at $\mathrm{p}=0.027$, a weak correlation, $\mathrm{R}^{2}=0.08$ ).

As we can see, there tends to be an apparent correlation between health parameters and welfare of working population in the first cluster; in other words, working population health tends to depend on how economically developed these territories are. As all the above mentioned correlations are reverse, we can state that if social-economic welfare grows, morbidity with temporary disability among working population decreases.

We also detected significant influences exerted by specific sanitary-hygienic factors of working population health in the first cluster; there were several "factor - effect" relationships reveled in those regions.
A number of days during which a worker was off sick per 100 employed men depended on an increase in a share of examined samples containing the following chemicals in concentrations higher than MPC: ammonia and ammonia ion (correlation coefficient was equal to (0.34), at $\mathrm{p}=0,007$, a moderate correlation, $\mathrm{R}^{2}=0.12$ ); boron (correlation coefficient was equal to $(0.50)$, at $p=0,004$, a significant correlation, $\mathrm{R}^{2}=0.25$ ), and there was also a correlation between this parameter and a number of days during which a worker was off sick per 100 employed (overall) (correlation coefficient was equal to $(0.47)$, at $p=0.000$, a moderate correlation, $\mathrm{R}^{2}=0.22$ ) and a number of temporary disability cases per 100 employed (correlation coefficient was equal to $(0.34)$, at $\mathrm{p}=0.008$, a moderate correlation, $\left.\mathrm{R}^{2}=0.11\right)$; manganese (correlation coefficient was equal to $(0.40)$, at $p=0.002$, a moderate correlation, $\mathrm{R}^{2}=0.16$ ), and there was also a correlation between this parameter and a number of days during which a worker was off sick per 100 employed (overall) (correlation coefficient was equal to (0.32), at $\mathrm{p}=0.001$, a moderate correlation, $\left.\mathrm{R}^{2}=0.10\right)$. There was a correlation between a number of days during which a worker was off sick per 100 employed men and a greater share of examined ambient air samples taken in urban and rural settlements that contained the following substances in concentrations higher than MPC: fluorine and its compounds (recalculated as per fluorine) (correlation coefficient was equal to $(0.42)$, at $\mathrm{p}=0.005$, a moderate correlation, $\mathrm{R}^{2}=0.17$ ); hydrogen fluoride (correlation coefficient was equal to $(0.40)$, at $p=0.008$, a moderate correlation, $\mathrm{R}^{2}=0.16$ ); this parameter also depended on a increase in a share of objects examined with laboratory tools and not conforming to sanitary standards as per electromagnetic radiation (correlation coefficient was equal to $(0.35)$, at $\mathrm{p}=0.006$, a moderate correlation, $\mathrm{R}^{2}=0.13$ ); on an increase in a share of objects that were examined with laboratory tolls and didn't conform to sanitary standards as per vibration (correlation coefficient was equal to (0.34), at $p=0.009$, a moderate correlation, $\left.\mathrm{R}^{2}=0.11\right)$.

An increase in a share of examined drinking water samples that contained boron in concentrations higher than MPC determined an increase in 
number of days during which a worker was off sick per 100 hundred employed women (correlation coefficient was equal to (0.54), at $\mathrm{p}=0.002$, a significant correlation, $\mathrm{R}^{2}=0.29$ ).

We determined the following correlations for the second cluster. Just as it was in the first one, when unemployment grew, it resulted in a decrease in a number of days during which a worker was off sick per 100 hundred employed men (correlation coefficient was equal to $(-0.57)$, at $p=0.000$, a significant correlation, $\mathrm{R}^{2}=0.32$ ), a decrease in a number of days during which a worker was off sick per 100 hundred employed people (overall) (a correlation coefficient was equal to $(-0.45)$, at $p=0.000$, a weak correlation, $\mathrm{R}^{2}=0.20$ ), and a decrease in a number of temporary disability cases per 100 employed (correlation coefficient was equal to (-0.36), at $\mathrm{p}=0.003$, a moderate correlation, $\mathrm{R}^{2}=0.13$ ). This can be due to people being afraid to lose a job as they are aware it will be rather difficult to find a new one.

When a ratio of average population incomes per capita to a living wage grew, it led to a decrease in a number of days during which a worker was off sick per 100 hundred employed women (a correlation coefficient was equal to $(-0.61)$, at $\mathrm{p}=0.000$, a significant correlation, $\mathrm{R}^{2}=0.38$ ), and there was also a decrease in this parameter per 100 employed people (overall) (a correlation coefficient was equal to $(-0.27)$, at $\mathrm{p}=0.032$, a weak correlation, $\mathrm{R}^{2}=0.07$ ).

It is interesting to note that an increase in an average duration of one temporary disability case correlated with a growth in various social and economic parameters at micro and macro-levels in the second cluster only. For example, growing expenses on public health care determined an increase in an average duration of one temporary disability case (correlation coefficient was equal to $(0.44)$, at $\mathrm{p}=0.000$, a moderate correlation, $\left.\mathrm{R}^{2}=0.20\right)$; the same effect was produced by growing average monthly wages paid to employed population (correlation coefficient was equal to $(0.54)$, at $\mathrm{p}=0.000$, a significant correlation, $\left.\mathrm{R}^{2}=0.30\right)$, an increase in a living wage (correlation coefficient was equal to (0.63), at $\mathrm{p}=0.000$, a significant correlation, $\mathrm{R}^{2}=0.40$ ). Growing investments into fixed capital per capita determined duration of temporary disability (correlation coefficient was equal to $(0.61)$, at $\mathrm{p}=0.000$, a significant correlation, $\mathrm{R}^{2}=0.37$, and the same effect was produced by an increase in number of families that were provided with housing or improved their housing conditions on their own taken as a ratio to overall population number (correlation coefficient was equal to $(0.33)$, at $p=0.008$, a moderate correlation, $\left.\mathrm{R}^{2}=0.11\right)$. Better housing conditions also led to a longer duration of one temporary disability case in the fourth cluster (correlation coefficient was equal to (0.62), at $p=0.000$, a significant correlation, $\mathrm{R}^{2}=0.38$ ). Number of nurses (per 1,000 people) in the $2^{\text {nd }}$ and $4^{\text {th }}$ clusters had a positive correlation with an average duration of one temporary disability case (correlation coefficient was equal to (0.59) and $(0.55)$, at $\mathrm{p}=0.000$, a significant correlation, $\mathrm{R}^{2}=0.37$ and $\mathrm{R}^{2}=0.31$ respectively). Duration of a disease case in other clusters correlated with only one or two socioeconomic factors but in the second cluster there were six such parameters; and it is only in the second cluster that this correlation was solely positive while, for example, in the third cluster (which was "conditionally well") growing investments into fixed capital per capita resulted in a shorter duration of one temporary disability case (correlation coefficient was $(-0.28)$, at $\mathrm{p}=0.010$, a weak correlation, $\left.\mathrm{R}^{2}=0.08\right)$.

As for sanitary-hygienic factors, there were several most significant ones that determined parameters of working population health in the second cluster; they were:

- a share of examined drinking water samples that contained iron (including iron chloride) in concentrations higher than MPC; it resulted in greater number of days during which a worker was off sick per 100 employed men (correlation coefficient was equal to $(0.60)$, at $\mathrm{p}=0.000$, a significant correlation, $\left.\mathrm{R}^{2}=0.36\right)$ and women (correlation coefficient was equal to (0.38), at $\mathrm{p}=0.003$, a moderate correlation, $\left.\mathrm{R}^{2}=0.14\right)$, as well as per 100 employed population (overall) (correlation coefficient was equal to $(0.44)$, at $\mathrm{p}=0.000$, a moderate correlation, $\left.\mathrm{R}^{2}=0.20\right)$; this sanitary-hygienic parameter also caused a growth in a number of temporary disability cases (correlation coefficient was equal to $(0.41)$, at $\mathrm{p}=0.000$, a moderate correlation, $\left.\mathrm{R}^{2}=0.17\right)$ 
- a share of drinking water samples that contained manganese in concentrations higher than MPC resulted in a greater number of days during which a worker was off sick per 100 employed men (correlation coefficient was equal to (0.34), at $\mathrm{p}=0.009$, a moderate correlation, $\mathrm{R}^{2}=0.11$ ); the same was detected for excessive concentrations of copper in drinking water (correlation coefficient was equal to $(0.38)$, at $\mathrm{p}=0.006$, a moderate correlation, $\mathrm{R}^{2}=0.15$ )

- a share of examined soil samples taken in settlements that did not conform to hygienic standards as per cadmium resulted in a growing number of days during which a worker was off sick per 100 employed men (correlation coefficient was equal to $(0.30)$, at $\mathrm{p}=0.006$, a weak correlation, $\mathrm{R}^{2}=0.09$ ); the same effect was produced by a share of soil samples not conforming hygienic standards as per microbiological parameters (correlation coefficient was equal to $(0.31)$, at $p=0.012$, a moderate correlation, $\left.\mathrm{R}^{2}=0.10\right)$, and this parameter also correlated with a greater number of days during which a worker was off sick per 100 employed people (overall) (correlation coefficient was equal to $(0.47)$, at $p=0.012$, a moderate correlation, $\mathrm{R}^{2}=0.22$ ) and a greater number of temporary disability cases per 100 employed people (correlation coefficient was equal to (0.53), at $\mathrm{p}=0.000$, a significant correlation, $\left.\mathrm{R}^{2}=0.28\right)$. A greater share of soil samples not conforming to hygienic standards as per radioactive substances led to a greater number of days during which a worker was off sick per 100 employed men (correlation coefficient was equal to (0.34), at $p=0.006$, a moderate correlation, $\mathrm{R}^{2}=0.12$ ); the same effect was produced by soils samples not conforming to standards as per sanitary-chemical parameters (correlation coefficient was equal to $(0.37)$, at $\mathrm{p}=0.003$, a moderate correlation, $\mathrm{R}^{2}=0.13$ ). A higher share of soils samples not conforming to hygienic standards as per lead contents resulted in a greater number of days during which a worker was off sick per 100 employed people (overall) (correlation coefficient was equal to $(0.35)$, at $\mathrm{p}=0.000$, a moderate correlation, $\mathrm{R}^{2}=0.12$ ) and in a greater number of temporary disability cases per 100 employed people (overall) (correlation coefficient was equal to $(0.30)$, at $\mathrm{p}=0.000$, a weak correlation,
$\mathrm{R}^{2}=0.09$ ); a greater share of soils samples deviating from standards as per heavy metals contents led to a greater number of days during which a worker was off sick per 100 employed men (correlation coefficient was equal to $(0.32)$, at $\mathrm{p}=0.011$, a moderate correlation, $\mathrm{R}^{2}=0.10$ ), a greater number of days during which a worker was off sick per 100 employed (overall) (correlation coefficient was equal to (0.31), at $\mathrm{p}=0.000$, a moderate correlation, $\mathrm{R}^{2}=0.10$ ), and a greater number of temporary disability cases per 100 employed (overall) (correlation coefficient was equal to $(0.33)$, at $\mathrm{p}=0.000$, a moderate correlation, $\left.\mathrm{R}^{2}=0.11\right)$.

Conclusions. RF regions were assigned into four various clusters as per a set of sanitary-hygienic and social-economic parameters; regions in each cluster have similar "background" for formation of working population's health. The first cluster, with the most adverse conditions, included 19 RF regions; there were high shares of examined ambient air samples and soils samples taken in settlements that contained adverse chemicals in concentrations higher than MPC and didn't conform to hygienic standards as per sanitary-chemical parameters, a significant share of dilapidated housing in the overall housing stock, and high average duration of one disease case. The second cluster, "moderately adverse" one, included 21 RF regions; there were high shares of examined water samples taken from centralized water supply systems that didn't conform to hygienic standards as per sanitary-chemical parameters, the highest number of days and cases of temporary disability per 100 employed (overall, men, and women). The third cluster, or "conditionally well" one, included 29 RF regions; there was the lowest shares of dilapidated housing, and sanitary-hygienic parameters that didn't conform to hygienic standards were lower than on average in the country. The fourth cluster, or the most favorable one, included $13 \mathrm{RF}$ regions; there was the highest purchasing power and gross regional products per capita, and sanitary-hygienic parameters that deviated from standards were lower than on average in the country.

We detected negative correlations between health parameters and certain social and economic parameters in the first ("the most 
adverse") cluster; these parameters were investments into fixed capital per capita, living wage, average population income per capita, average monthly wages paid to employed people, and unemployment rate (calculated as per WLO methodology). It substantiates the necessity to increase welfare of population living in RF regions from this cluster as it will lead to improvement in their health.

As for the second cluster ("moderately adverse" one), we detected the strongest correlations between health parameters and sanitary-hygienic parameters, especially those related to drinking water and soil samples.

Cluster analysis results revealed that an average share of water samples taken from water supply systems that didn't conform to hygienic standards as per sanitary-hygienic parameters amounted to $39 \%$ in $\mathrm{RF}$ regions from the second cluster (and it was more than
2 times higher than on average in the country and in other clusters); given that, it is quite reasonable to pay greater attention exactly to sanitary-hygienic parameters in the second cluster.

Such a social-economic parameters as unemployment rate turned out to be significant for health formation in all four clusters.

Therefore, when developing federal and regional programs aimed at preserving and improving health of overall population and employable population in particular, it is necessary to take detected risk factors into account depending on a cluster a territory belongs to and treat them as priority ones.

Funding. The research was not granted any sponsor support.

Conflict of interest. The authors state there is no any conflict of interest.

\section{References}

1. Bang K.M., Attfield M.D., Wood J.M., Syamlal G. National trends in silicosis mortality in the United States, 1981-2004. American Journal of Industrial Medicine, 2008, vol. 51, no. 9, pp. 633-639.

2. Burgard S.A., Lin K.Y. Bad jobs, bad health? How work and working conditions contribute to health disparities. American Behavioral Scientist, 2013, vol. 57, no. 8, pp. 1105-1127.

3. Dong X.S., Wang X., Largay J.A. Occupational and non-occupational factors associated with work-related injuries among construction workers in the USA. International Journal of Occupational and Environmental Health, 2015, vol. 21, no. 2, pp. 142-150. DOI: 10.1179/2049396714Y.0000000107

4. Jones M.K., Latreille P.L., Sloane P.J., Staneva A.V. Work-related health risks in Europe: Are older workers more vulnerable? Social science \& Medicine, 2013, no. 88, pp. 18-29.

5. Oortwijn W., Nelissen E., Adamini S., Van Den Heuvel S., Geuskens G., Burdof L. Health of people of working age. Full Report. Luxembourg, European Commission Directorate General for Health and Consumers Publ., 2011. DOI: 10.2772/62393

6. Campos-Serna J., Ronda-Pérez E., Artazcoz L., Moen B.E., Benavides F.G. Gender inequalities in occupational health related to the unequal distribution of working and employment conditions: a systematic review. International Journal for Equity in Health, 2013, no. 12, pp. 61-80. DOI: 10.1186/1475-9276-12-57

7. Bukhtiyarov I.V., Izmerov N.F., Tikhonova G.I., Churanova A.N., Gorchakova T.Yu., Bryleva M.S. [et al.]. Work conditions as a risk factor mortality increase in able-bodied population. Meditsina truda i promyshlennaya ekologiya, 2017, no. 8, pp. $43-49$ (in Russian).

8. Izmerov N.F., Tikhonova G.I., Gorchakova T.Yu. Working conditions and mortality of men of working age in Russia (for example of the Murmansk region). Vestnik Rossiiskoi akademii meditsinskikh nauk, 2013, no. 9, pp. 32-36 (in Russian).

9. Zaitseva N.V., May I.V., Kostarev V.G., Bashketova N.S. On risk-oriented model of sanitary epidemiologic surveillance in occupational hygiene. Meditsina truda i promyshlennaya ekologiya, 2015, no. 8, pp. 1-6 (in Russian).

10. Tomakova I.A., Tomakov V.I. The state of working conditions, occupational diseases, industrial injuries at enterprises of the Russian Federation and the tasks that must be solved. Proceedings of SouthWest State University. Series Technics and Technologies, 2016, vol. 19, no. 2, pp. 95-107.

11. Piktushanskaya T.E., Bykovskaya T.Yu. Influence of work conditions on health of working population in Rostov region. Meditsina truda i promyshlennaya ekologiya, 2011, no. 3, pp. 23-27.

12. Dukhin O.Ya., Penzina N.N., Zheleznaya T.Yu. Health and working conditions of the working population of the Vologda region. Vestnik Sankt-Peterburgskoi gosudarstvennoi meditsinskoi akademii im. I.I. Mechnikova, 2009, no. 2, pp. 22-25. 
13. Topalov K.P., Schegolskaya O.V. Problems of the health of the working population in the Khabarovsk region: state and trends. Zdravookhranenie Dal'nego Vostoka, 2016, vol. 70, no. 4, pp. 5-15.

14. Maliutina N.N., Eremeyev R.B., Taranenko L.A., Tolkatch A.S., Kostarev V.G. Some health parameters of working population in Perm area, and objectives to health improvement for recent years. Meditsina truda i promyshlennaya ekologiya, 2012, no. 12, pp. 4-8.

15. Zhernakova G.N., Gudinova Z.V., Gegechkori I.V., Blinova E.G., Tolkova E.I. Methodological approaches to occupational morbidity estimation in the Omsk region during the interregional comparisons. Fundamental'nye issledovania, 2011, vol. 9, no. 2, pp. 245-248.

16. Gudinova Zh.V., Zhernakova G.N. Occupational morbidity in Russia: regional variability and formation factors. Sotsial'nye aspekty zdorov'ya naseleniya, 2011, vol. 17, no. 1, pp. 9 .

17. Mikhailuts A.P., Pershin A.N., Vostrikova E.A. Occupational hygiene and health condition of workers of chemical enterprises in the climate of western Siberia. Acta Biomedica Scientifica, 2005, vol. 40, no. 2 , pp. $45-50$.

18. Chashchin V.P., Gudkov A.B., Popova O.N., Odland J.O., Kovshov A.A. Description of main heath deterioration risk factors for population living on territories of active natural management in the Arctic. Ecologiya cheloveka, 2014, no. 1, pp. 3-12.

19. Oleshenko A.M., Zakharenkov V.V., Sourzhikou D.V., Panaiotti E.A., Tsai L.V. Evaluating risk of morbidity among workers of coal open-cast mines in Kuzbass. Meditsina truda i promyshlennaya ekologiya, 2006, no. 6, pp. 13-16.

20. Shatz N.N., Shatz M.M. Regional characteristics of health of North population. Yakutskii meditsinskii zhurnal, 2011, vol. 35, no. 3, pp. 65-67.

21. Solodukhina D.P., Zavialova N.A. Working citizens behavior in situation of health disorder. Sotsiologicheskie issledovaniya, 2011, vol. 327, no. 7, no. 122-125.

22. Bulanov V. Improtance of healthy lifestyle for the production industry employees in the modern context. Sotsial'nye aspekty zdorov'ya naseleniya, 2015, vol. 41, no. 1, pp. 1-9.

23. Malutina N.N., Lebedeva T.M., Lepikhina T.L., Karpovich Y.V., Taranenko L.A., Tolkach A.S., Naumkin A.V. Necessity of the health-saving behavior formation at industrial enterprises in perm region. Zdorovie sem'i - 21 vek, 2013, vol. 3, no. 3, pp. 102-103.

24. Pastukhova E.Ya. The relationship of public health and socio-economic factors: Evidence from the Siberian regions of Russia. Regional'naya ekonomika: teoriya i praktika, 2016, vol. 433, no. 10, pp. 180-189.

25. Derstuganova T.M., Velichkovskii B.T., Gurvich V.B., Varaksin A.N., Malykh O.L., Kochneva N.I., Yarushin S.V. The impact of socio-economic factors on mortality rates among the working age population (the experience of the Sverdlovsk region). Zdorov'e naselenia i sreda obintania, 2013, vol. 246, no. 9, pp. 12-14.

26. Fang P., Dong S., Xiao J., Liu C., Feng X., Wang Y. Regional inequality in health and its determinants: evidence from China. Health Policy, 2010, vol. 94, no. 1, pp. 14-25.

27. Van Hemelrijck W.M.J., Willaert D., Gadeyne S. The geographic pattern of Belgian mortality: can socio-economic characteristics explain area differences? Archives of Public Health, 2016, no. 74, pp. 1-10. DOI: 10.1186/s13690-016-0135-y

28. Maguire E.R., Monsivais P. Socio-economic dietary inequalities in UK adults: an updated picture of key food groups and nutrients from national surveillance data. The British Journal of Nutrition, 2015, vol. 113, no. 1, pp. 181-189. DOI: 10.1017/S0007114514002621

29. Wang Q., Shen J.J., Cochran C. Unemployment Rate, Smoking in China: Are They Related? International Journal of Environmental Research and Public Health, 2016, vol. 13, no. 1, pp. 113. DOI: 10.3390/ijerph13010113

30. Rezayatmand R., Pavlova M., Groot W. Socio-economic Aspects of Health-Related Behaviors and Their Dynamics: A Case Study for the Netherlands. International Journal of Health Policy and Management, 2016, vol. 5, no. 4, pp. 237-251. DOI: 10.15171/ijhpm.2015.212

31. Velichkovskii B.T. Human health and social stress. Russian Journal of Rehabilitation Medicine, 2016, no. 1, pp. 3-18.

Lebedeva-Nesevrya N.A., Barg A.O., Tsinker M.Yu., Kostarev V.G. Assessment of correlation between heterogeneous risk factors and morbidity among working population in russian regions with different background of health formation. Health Risk Analysis, 2019, no. 2, pp. 91-100. DOI: 10.21668/health.risk/2019.2.10.eng

Received: 5.06.2019

Accepted: 13.06 .2019

Published: 30.06.2019 